九病虫研会報 $62: 77-81 （ 2016 ）$

Kyushu Pl. Prot. Res. 62 : 77-81 (2016)

\title{
ワタアブラムシに対する薬剤感受性検定法の違いが 検定結果に及ぼす影響
}

\author{
松浦明 ${ }^{12)} \uparrow$ \\ ( ${ }^{1}$ 宮崎県総合農業試験場・ ${ }^{2)}$ 九州大学大学院生物資源環境科学府)
}

\begin{abstract}
Effect of different insecticide bioassay methods on mortality of Aphis gossypii
Glover. Akira Matsuura ${ }^{12) \dagger}\left({ }^{1}\right.$ Miyazaki Agricultural Research Institute, Miyazaki, Miyazaki 880-0212, Japan, ${ }^{2}$ Graduate School of Bioresource and Bioenvironmental Sciences, Kyushu University, Fukuoka 812-8581, Japan)
\end{abstract}

ワタアブラムシの薬剤感受性検定には様々な手法が利用されているため, 結果の相互比較が困 難な状況である。統一的な薬剤感受性検定法の基準を検討するため, 植物体浸漬法である Munger cell 法と幼苗処理法の検定結果の比較を行った。幼苗処理法はキュウリ幼苗, Munger cell 法はキュウリ成葉を用いて，イミダクロプリド，ニテンピラム，アクリナトリン，アセフェー ト，ピメトロジンに対するネオニコチノイド剤抵抗性ワタアブラムシ無翅雌成虫の感受性を調査 した。イミダクロプリド2,000倍の補正死虫率は, Munger cell 法が $6.7 \%$ であったのに対し, 幼苗 処理法では $80.0 \%$ とかなり高かった。そこで各薬剤の $\mathrm{LC}_{50}$ 值を比較した結果, Munger cell 法の

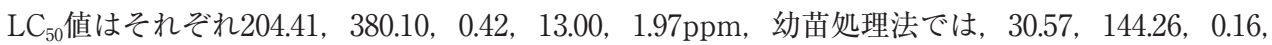
7.20, $0.74 \mathrm{ppm}$ となり, Munger cell 法は幼苗処理法より高い值を示した。したがって, 抵抗性害 虫の早期発見を目的に, 常用濃度のみで検定を行う場合は, Munger cell 法が適していると考え られた。

Keywords : cotton aphid, $\mathrm{LC}_{50}$, manger cell method, neonicotinoid, seedling treatment method

緒

\section{言}

ワタアブラムシ (Aphis gossypii Glover) は多くの 農作物を加害する重要害虫である。本種は殺虫剤に対 する抵抗性を発達させるため難防除害虫となっている。 1980年代には有機リン剤やカーバメート剤（浜, 1987），そして合成ピレスロイド剤（西東，1990）へ の強い抵抗性が確認されている。1990年代にアブラム シ類に卓効を示すネオニコチノイド剂が登場した後は, ネオニコチノイド剤やその他の薬剤への抵抗性発達は 認められず，抵抗性問題は沈静化したようにみえた。 しかし，2012年に宮崎県および大分県のピーマンと キュウリで採集されたワタアブラムシは, 複数のネオ ニコチノイド剤に対して高い抵抗性を示し, 実用的な 防除効果の低下が認められた（岡崎, 2013; Matsuura and Nakamura, 2014)。

matsuura-akira@pref.miyazaki.lg.jp
ネオニコチノイド剤抵抗性ワタアブラムシに対する 他系統の殺虫剂の殺虫効果が既に明らかにされていた ことから, 生産現場では代替薬剤による防除が可能と なっている（松浦, 2015）。しかし, 他系統の殺虫剤 に対する抵抗性をも併せ持つワタアブラムシの出現が 懸念されている。

殺虫剂抵抗性害虫の基幹防除剤に対する抵抗性レベ ルを正確に把握することは, 効率的防除体系の構築と 害虫の抵抗性管理において重要である。また, 既知の 代替薬剂の感受性を明らかにすることも，生産現場に おける被害拡大を防ぐための防除体系を構築する上で 重要である。そのためには, 対象害虫の抵抗性レベル を相対的に比較評価できる情報が必要である。

ワタアブラムシを含むアブラムシ類に対する薬剤の 殺虫効果抢よび薬剂感受性は, 局所施用法（西東ら, 1995 ；西東，2013）や虫体浸漬法（浜， 1987）および 植物体浸漬法（熊本県, 2000 ; 岡崎, 2013 ; Matsuura and Nakamura, 2014）など，様々な生物検定法によ 
り明らかにされてきた。局所施用法は, 各殺虫剤の原 体を用い, 対象害虫の体重当たりの致死薬量を明らか にできるため，相互比較が可能である（竹内，2013）。 しかしながら, 使用器材が高価であり, 手法も簡便と は言い難い。虫体浸漬法や植物体浸漬法は, 局所施用 法に比べ簡便であるが，検定薬剤として市販品を用い る上，検定環境により，虫体ならびに植物体への薬液 の付着量が一定でない欠点がある（細辻，1985）。こ のため, 異なる試験機関で実施された検定結果の相互 比較が困難な状況となっている。

ネオニコチノイド剤抵抗性ワタアブラムシの感受性 調査では, 植物体浸漬法である幼苗処理法（Matsuura and Nakamura, 2014) や Munger cell 法（岡崎ら,

2013）が利用されてきた。両手法は, 局所施用法や虫 体浸漬法より簡便なため, ワタアブラムシの薬剤抵抗 性モニタリングに適していると考えるが，上述したよ うな欠点（細辻，1985）を持つため, 両手法間で検定 結果の差が生じる可能性が大きい。したがって, 植物 体浸漬法を用いて, ワタアブラムシの薬剤抵抗性の状 況を効率的にモニタリングするためには，両手法の特 性を明らかにし，検定薬剤に適した検定法や検定期間 等の統一的な基準を示すことが必要である。

そこで本研究では, 両手法の特性と各検定結果の比 較を行い, ワタアブラムシの薬剤抵抗性をモニタリン グするための手法としての適性を評価したので報告す る。

本研究は, 農林水産省委託研究プロジェクト「ゲノ ム情報等を活用した薬剤抵抗性管理技術の開発 (PRM2103)」により実施した。

\section{材料および方法}

\section{1. 供試ワタアブラムシ}

検定に使用したワタアブラムシは 2012 年に宮崎県串 間市の冬春キュウリほ場から採集後, 無翅胎生雌成虫 1 個体からキュウリを用いて累代飼育を行った系統を 用いた。この系統はネオニコチノイド剤抵抗性である ことを確認済みである（Matsuura and Nakamura, 2014）。な㧍，累代飼育中に殺虫剤の散布は行ってい ない。

\section{Munger cell 法および幼苗処理法における各種 殺虫剤の効力の違い（試験 1 ）}

供試薬剂はネオニコチノイド系のイミダクロプリド 水和剂およびニテンピラム水溶剤, ピレスロイド系の アクリナトリン水和剤, 有機リン系のアセフェート水 和剂, ピメトロジン系のピメトロジン顆粒水和剤の 5
剤を用いた。薬片は 5 ～6段階で倍量希釈した薬液を 検定に供試した（第 1 表）。各希釈倍率とも 1 区10頭 の 3 反復で実施した。

薬液処理は幼苗処理法（曽根ら, 1998 ; 熊本県, 2000)と Munger cell 法 (Immaraju et al., 1992 ; 岡 崎ら，2014）に基づき, 後述のとおり各薬液に植物体 を浸漬した。幼苗処理法は, 検定植物として播種 6 ～ 8 日後のキュウリ（品種：エクセレント節成 2 号）の 幼苗を供試した。キュウリ幼苗は水道水を入れた管瓶 (直径 $15 \mathrm{~mm}$ 高さ $40 \mathrm{~mm}$ ) に根元を入れ，パラフィルム ${ }^{\circledR}$ で固定した。これを展着片トリトンX-100（ポリオキ シェチレン（10）オクチルフェニルエーテル） 2,000 倍を添加した各薬液に10秒間浸漬した。風乾後, スチ ロール容器（直径 $42 \mathrm{~mm}$, 高さ $75 \mathrm{~mm}$, 容量 $70 \mathrm{ml}$ ) の蓋 の中央に直径 $15 \mathrm{~mm}$ の穴を 1 力所あけ，管瓶を差し込み 固定し, 底面を切り取ったスチロール容器（側面にテ トロンゴースで覆った直径 $6 \mathrm{~mm}$ の穴 4 カ所を開けた) を，植物体に被せた。上部からワタアブラムシ無翅雌 成虫10頭を接種し，開口部をパラフィルムで覆った。

Munger cell 法による検定は, 下から順にアクリル 板 $(5 \times 7 \mathrm{~cm}$, 厚さ $2 \mathrm{~mm})$, 約 $1 \mathrm{ml}$ の水を滴下した クッキングペーパー $(5 \times 7 \mathrm{~cm})$, 薬液に 10 秒間浸漬・ 風乾した直径 $5 \mathrm{~cm}$ のキュウリ葉片, その上に直径 $4 \mathrm{~cm}$ の穴を開けたアクリル板 $(5 \times 7 \mathrm{~cm}$, 厚さ $5 \mathrm{~mm})$ を重 ねた検定容器を用いた。容器内の葉片上に無翅雌成虫 を接種後, 容器上にテトロンゴース (200メッシュ) を張った穴あきアクリル板 $(5 \times 7 \mathrm{~cm}$, 厚さ $2 \mathrm{~mm}$, 穴 径 $4 \mathrm{~cm}$ ）をかぶせ，二方をクリップで固定した。なお 検定期間中はワタアブラムシ接種面を上に向けて静置 した。

両手法とも無翅雌成虫を接種後, $25^{\circ} \mathrm{C} 16 \mathrm{~L} 8 \mathrm{D}$ の条 件下で静置し, イミダクロプリド, ニテンピラム, ア クリナトリンおよびアセフェートは72時間後, 遅効性 薬剤であるピメトロジンは96時間後に実体顕微鏡下で 生死の判定を行った。死虫率はAbbott（1925）の補 正式を用いて求め, Probit 法により $\mathrm{LC}_{50}$ 值を算出した。 検定法間の補正死虫率は, アークサイン変換後に一元 配置分散分析（ANOVA）を用いて比較した。解析に は統計解析ソフト R（version 2.15.1）を用いた。

\section{Munger cell 法の供試葉片の上下方向が殺虫剤 の効力に及ぼす影響（試験 2)}

Munger cell 法における供試虫の接種面の上下方向 を変えた場合の $\mathrm{LC}_{50}$ 值を調査した。接種面が上の場 合は, 穴あき板の面が上を向き, 供試ワタアブラムシ が検定植物の上に存在する。下向きはその逆である。 
第 1 表 Munger cell 法と幼苗処理法によって推定されたネオニコチノイド剤抵抗性ワタアブラムシに対する各種薬剤の $\mathrm{LC}_{50}$ 值

\begin{tabular}{|c|c|c|c|c|c|c|c|c|c|c|c|}
\hline \multirow{2}{*}{ 系統 ${ }^{\text {) }}$} & \multirow{2}{*}{ 供試薬剤 } & \multirow{2}{*}{$\begin{array}{l}\text { 有効 } \\
\text { 成分 } \\
(\%)\end{array}$} & \multirow{2}{*}{\multicolumn{3}{|c|}{$\begin{array}{c}\text { 検定濃度 } \\
\text { (ppm) }\end{array}$}} & \multirow{2}{*}{\multicolumn{2}{|c|}{ 希釈倍率 }} & \multirow{2}{*}{ （倍） } & \multicolumn{2}{|c|}{$\mathrm{LC}_{50}$ 值 $(\mathrm{ppm})$} & \multirow{2}{*}{$\begin{array}{c}\mathrm{LC}_{50} \text { 值比 } \\
(\text { 倍 })^{\mathrm{b})}\end{array}$} \\
\hline & & & & & & & & & Munger cell 法 & 幼苗処理法 & \\
\hline ネオニコチノイド (4A) & イミダクロプリド水和剤 & 10 & 25 & $\sim$ & 400 & 4,000 & $\sim$ & 250 & 204.41 & 30.57 & 6.7 \\
\hline ネオニコチノイド(4A) & ニテンピラム水溶剤 & 10 & 25 & $\sim$ & 400 & 4,000 & $\sim$ & 250 & 380.10 & 144.26 & 2.6 \\
\hline ピレスロイド(3A) & アクリナトリン水和剤 & 3 & 0.0375 & $\sim$ & 0.6 & 800,000 & $\sim$ & 50,000 & 0.42 & 0.16 & 2.6 \\
\hline 有機リン (1B) & アセフェート水和剤 & 50 & 0.78 & $\sim$ & 25 & 640,000 & $\sim$ & 20,000 & 13.00 & 7.20 & 1.8 \\
\hline ピメトロジン (9B) & ピメトロジン水和剤 & 50 & 0.3125 & $\sim$ & 10 & 800,000 & $\sim$ & 50,000 & 1.97 & 0.74 & 2.7 \\
\hline
\end{tabular}

a) IRAC の分類に従った. b) $\mathrm{LC}_{50}$ 值比 $=$ Munger cell 法値 /幼苗処理法値.

試験は 2 回行い, 供試薬剤はイミダクロプリド水和剤 を用いた。希釈倍率や Munger cell 法の試験手順は試 験 1 と同様である。

\section{結 果}

\section{Munger cell 法および幼苗処理法における各種}

\section{殺虫剤の効力の違い（試験 1)}

各薬片の補正死虫率は，イミダクロプリドでは250 〜2,000倍, ニテンピラムでは 250 倍および500倍, ア クリナトリンでは 5 万倍拉よび10万倍, ピメトロジン では 5 万倍と 40 万倍で, 補正死虫率に両手法間で有意 差が認められた（第 1 図）。なかでも，イミダクロプ リド2,000倍希釈では Munger cell 法の6.7\%に対し， 幼苗処理法が $80.0 \%$ ，ニテンピラムの500倍では Munger cell 法の $20.0 \%$ に対し, 幼苗処理法が $66.7 \%$ と, Munger cell 法に比べて幼苗処理法の結果がかなり高 くなった。これら以外でもニテンピラム 4,000 倍とア セフェートの20,000倍を除き, Munger cell 法より幼 苗処理法の值が高かった。(第 1 図)。

推定された $\mathrm{LC}_{50}$ 值は検定法によって大きく異なっ た。 Munger cell 法の $\mathrm{LC}_{50}$ 值は, ネオニコチノイド剤 のイミダクロプリドが204.41ppm, ニテンピラムが $380.10 \mathrm{ppm}$ であったのに対し，幼苗処理法では $30.57 \mathrm{ppm}$ と144.26ppm と低かった。Munger cell 法 の $\mathrm{LC}_{50}$ 值は幼苗処理法より高い值を示し, 幼苗処理 法の值に対する Munge cell 法の值（ $\mathrm{LC}_{50}$ 值比）は, それぞれの薬剤で 6.7 倍と 2.6 倍の差が認められた。他 の 3 薬剤のアクリナトリン, アセフェート, ピメトロ ジンの 3 剂の $\mathrm{LC}_{50}$ 值も Munger cell 法が幼苗処理法 より高く, 1.8〜2.7倍の差が認められた（第 1 表）。

\section{Munger cell 法の供試葉片の上下方向が殺虫剤 の効力に及ぼす影響（試験 2）}

ワタアブラムシの接種面を下に向けた場合の $\mathrm{LC}_{50}$ 值は，1回目が72.2ppm，2 回目が70.1ppm であった。
第2表 Munger cell 法のワタアブラムシ接種面の方向 が $\mathrm{LC}_{50}$ 值に及ぼす影響

\begin{tabular}{|c|c|c|c|}
\hline \multirow{2}{*}{ 供試薬剤 } & \multirow{2}{*}{$\begin{array}{l}\text { 接種 } \\
\text { 面の } \\
\text { 方向 }\end{array}$} & \multicolumn{2}{|c|}{$\mathrm{LC}_{50}$ 値（ppm） } \\
\hline & & 1 回目 & 2 回目 \\
\hline \multirow{2}{*}{ イミダクロプリド水和剤 } & 下 & 72.2 & 70.1 \\
\hline & 上 & 78.0 & 50.1 \\
\hline
\end{tabular}

上に向けた場合は78.0ppm と50.1ppm となり，接種面 の上下方向の違いに大きな差は認められなかった（第 2 表)。

\section{考察}

今回比較した Munger cell 法と幼苗処理法は, どち らも薬液に浸漬後風乾した検定植物にワタアブラムシ を接種しており，基本的な手順は同じである。しかし， Munger cell 法の補正死虫率は, 幼苗処理法より低く $\mathrm{LC}_{50}$ 值は幼苗処理法より高い值を示した。特にイミダ クロプリドにおける両検定法の差は $\mathrm{LC}_{50}$ 值比で 6.7 倍 と大きく, ワタアブラムシでは類似の検定手法であっ ても，検定結果が異なることが明らかとなった（第 1 表)。

農業害虫の薬椷感受性の調査では，まず複数の薬剤 の常用濃度における感受性を調查し, 感受性低下が疑 われる薬剂を対象に, $\mathrm{LC}_{50}$ 值を求め抵抗性レベルを比 較することが多い（例えばワタアブラムシでは，西東， 1990 ; 早田・大久保, 1992 ; アザミウマ類では, 西ら, 2013 ; 岡崎ら, 2014など)。そのため, 常用濃度での 薬剤感受性を適切に把握することが, 抵抗性害虫の早 期発見には重要である。今回の試験においては, 常用 濃度である希釈倍率2,000倍の補正死虫率が, ニテン ピラムでは Munger cell 法抒よび幼苗処理法とも $20 \%$ 以下と低かったため, どちらの手法でも感受性低下を 判定することが可能であった（第 1 図）。一方，イミ 
ダクロプリドの補正死虫率は， Munger cell 法が $6.7 \%$ と低かったのに対し, 幼苗処理法は $80.0 \%$ と高い死亡 率を示した (第 1 図)。このため, 常用濃度のイミダ クロプリドの検定において，幼苗処理法ではネオニコ チノイド剂に対する感受性低下を見逃す可能性が考え られる。このことから，抵抗性の早期発見を目的に， 常用濃度のみで検定を行う場合は, Munger cell 法が 幼苗処理法より適した手法であると考えられた。ただ し, Munger cell 法では，検定開始72時間以降に葉片 が稀に乾燥枯死し，試験が遂行できなかった事例が認 められた。そのため, ピメトロジンのような 96 時間後 以降に生死の判定を行う必要がある遅効性殺虫剤では, 反復数を増やすなど，葉片の乾燥枯死対策が必要とな る。72時間後までに判定する場合では Munger cell 法 を用い，遅効性薬剤の検定を実施する場合は，幼苗処 理法を用いるなど状況に応じて使い分けることも重要 と考えられる。
今回，手法により結果が異なった要因はいくつか考 えられる。田中・浅野（1978）がハスモンヨトウ Spodoptera litura (Fabricius) 3 齢幼虫に対して行っ た葉片浸漬法と虫体浸漬法の比較では, アセフェート, プロチホス, P A P の 3 剤では葉片浸漬法より虫体浸 漬法の死虫率が明らかに低かった。これはこの 3 剂が 経皮毒性より経口毒性が高いことによるものと推察さ れている。つまり供試虫に対する各供試薬剤の作用性 の違いが要因として挙げられる。しかし，今回ワタア

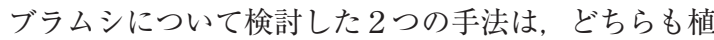
物体浸漬法であるため, 供試薬剤の作用性は同等と考 えられる。また, 供試した 5 薬剤全てにおいて,

Munger cell 法の $\mathrm{LC}_{50}$ 值の方が高かった。以上のこと からも, 各薬剤の作用性が補正死虫率の違いに影響し たとは考えられない。

次に両検定法の検定位置の高さの違いが影響したの ではないかと考えた。幼苗処理法では接種位置が検定

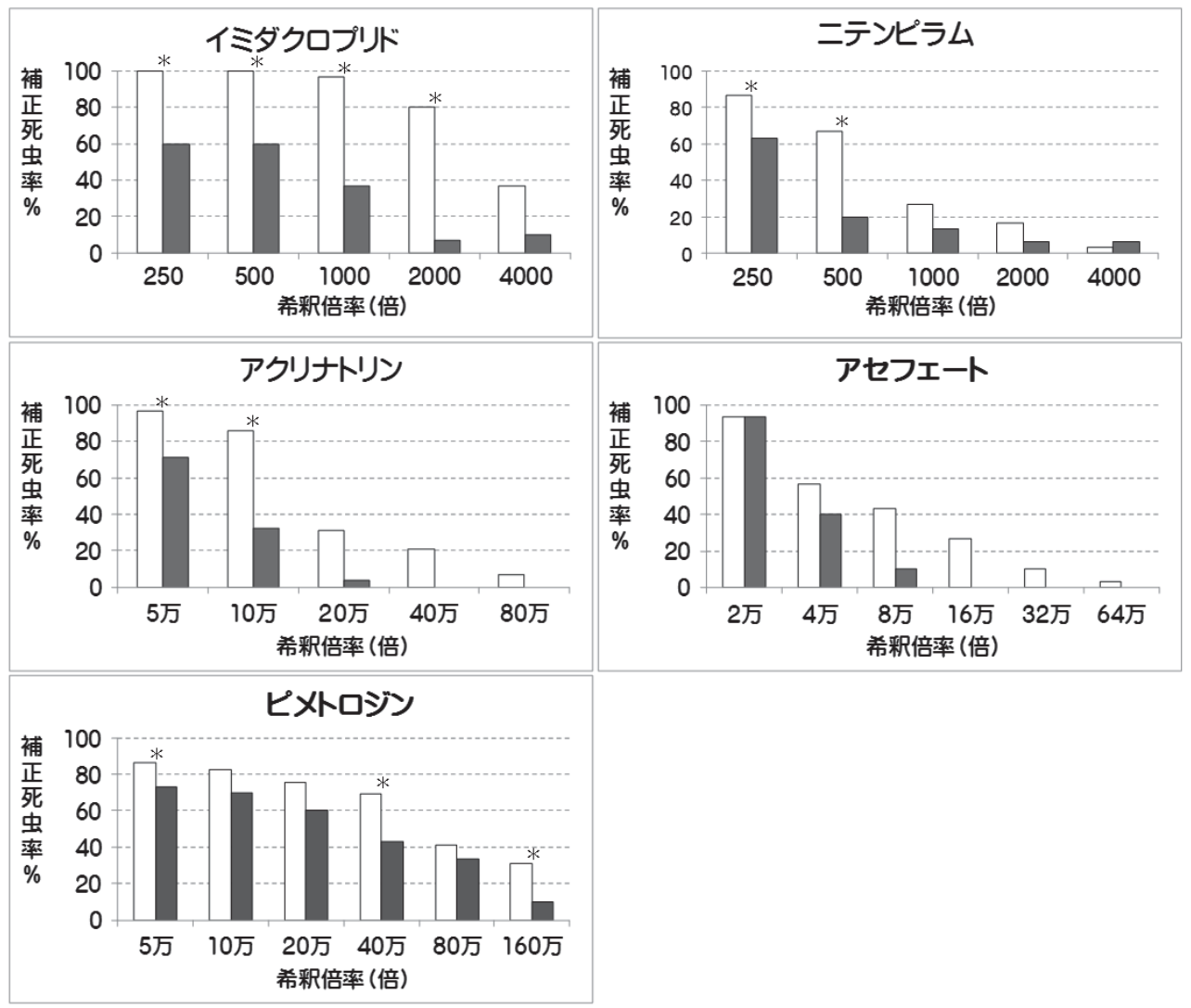

第1図 Munger cell 法および幼苗処理法における各種殺虫剤の補正死虫率.

口は Munger cell 法, $\square$ は幼苗処理法を示す。“は両検定法の同一希釈倍率間で 有意差があることを示す（アークサイン変換後一元配置分散分析， $P<0.05 ）$. 
容器の底から約 $5 \mathrm{~cm}$ 高さに存在する。そのため, こ のような試験状況では, 検定濃度が致死濃度に至って いなくても, 衰弱し検定植物から落下して, 検定容器 の底部で死亡したと考えられる個体が観察されること が多い。したがって, 本法では死虫率が高く評価され る傾向にあると考えられた。一方, Munger cell 法で は，接種面を上に向けて検定した。この状態では，ワ タアブラムシの下に, 供試植物が存在するため, 弱っ た個体でも吸汁が可能で試験期間内に死に至らないの ではないかと考えられた。そこで試験 2 では，供試虫 の接種面を葉の下側にして再検定を行った。上記の仮 説が正しいのであれば，下側に接種したアブラムシは 衰弱すると幼苗処理法同様に落下するため, 上面に接 種した場合より死亡率が高くなるはずである。しかし， Munger cell 法接種面の上下の差異は, 死虫率に影響 を及ぼさなかった。この要因として Munger cell 法の 高さが $5 \mathrm{~mm}$ と低く，落下したワタアブラムシの再寄生 が可能となった可能性が考えられ, 今後, 高さを変え た条件で更に検討する必要がある。

今回, 2 種類の検定法の特性とその利用に関して注 意すべき点が明らかになった。今後は他の検定法やワ タアブラムシと同様に殺虫剂抵抗性が問題となってい るモモアカアブラムシ Myzus persicae (Sulzer) で の比較検討を実施し，アブラムシ類の統一的な検定条 件を明らかにする必要がある。

\section{引用文 献}

Abbott, W. S. (1925) A method of computing the effectiveness of an insecticide. J. Econ. Entomol. 18 : 265-267.

浜 弘司 (1987) アブラムシの薬剤抵抗性. 植物防疫 $41: 159-164$.

細辻豊二（1985）最新農薬生物検定法. 全国農村教育 協会 (東京), pp. 240.

Immaraju, J. A., T. D. Paine, J. A. Bethke, K. L. Robb and J. P. Newman (1992) Western flower thrips (Thysanoptera: Thripidae) resistance to insecticides in coastal California greenhouse. J. Econ. Entomol. 85 : 9-14.

熊本県農業研究センター（2000）ウリ科野菜幼苗を使 用したワタアブラムシの薬剤感受性検定法. 九州農 業研究成果情報 $15: 455-456$.

松浦 明（2015）宮崎県におけるネオニコチノイド剤 抵抗性ワタアブラムシの発生. 植物防疫 $69: 92-96$.
Matsuura, A. and M. Nakamura (2014) Development of neonicotinoid resistance in the cotton aphid Aphis gossypii (Hemiptera: Aphididae) in Japan. Appl. Entomol. Zool. 49 : 535-540.

西 優輔 ·佐野敏広・高馬浩寿・田中律子・長森茂之 （2013）岡山県の促成栽培ナスに扔けるミナミキイ ロアザミウマ個体群に対する各種薬剤の殺虫効果. 九病虫研会報 $59: 81-85$.

岡崎真一郎（2013）近年大分県の夏秋ピーマンで多発 生するワタアブラムシに対する各種薬剤の殺虫効果. 九病虫研会報 $59: 108$ (講要)

岡崎真一郎 · 大坪亮介 · 加藤幸太郎 (2014) 大分県の 夏秋ピーマンに扔けるミカンキイロアザミウマ個体 群の薬剤殺虫効果とスピノサド感受性低下個体群の 初確認. 九病虫研会報 $60: 79-83$.

西東 力 (1990) ワタアブラムシ Aphis gossypii Gloverの薬剤抵抗性. III. 合成ピレスロイド剂抵 抗性個体群の発生. 応動昆 $34:$ 174-176.

西東 力 (2013) 野菜・花き害虫：アブラムシ類. 農 業害虫の薬剤感受性検定マニュアル（農業害虫の薬 剂感受性検定マニュアル編集委員会編)。日本植物 防疫協会 (東京) : pp. 79-82.

西東 力・浜 弘司・鈴木 健 (1995) ワタアブラム シ Aphis gossypii (Glover) の薬剂抵抗性クローン の各種薬剤に対する感受性と協力剂の影響. 応動昆 39 : 151-158.

曽根信三郎・牧 孝匡・岩谷宏司・大津悠一 (1998) キュウリ幼苗を用いたミナミキイロアザミウマの薬 剂効力検定法. 応動昆 42:215-220.

早田栄一郎・大久保宣雄（1992）果樹アブラムシ類の 薬剤抵抗性. 第 2 報. ワタアブラムシ野外個体群お よびクローンの薬剤感受性. 九病虫研会報 38 : 155-159.

竹内博昭（2013）局所施用法による薬剤感受性検定方 法の構築〜ミナミアオカメムシなどダイズを加害す るカメムシ類を対象として〜。農業害虫の薬剤感受 性検定マニュアル（農業害虫の薬剤感受性検定マ ニュアル編集委員会編)。日本植物防疫協会（東 京) : pp. 43-47.

田中浩一・浅野勝司（1978）殺虫剤の効力評価試験法 に関する研究. 第 1 報. ハスモンヨトウ幼虫に対す る試験. 九病虫研会報 $24: 121-122$.

(2016年 3 月21日受領, 7 月28日受理) 